\title{
PENERAPAN UU NO 7 TAHUN 2014 TENTANG PERDAGANGAN TERHADAP PRODUK YANG TIDAK BERLABEL BAHASA INDONESIA DALAM PERSPEKTIF ETIKA BISNIS ISLAM (STUDI SUPERMARKET NIAGA CAKRA NEGARA MATARAM)
}

\author{
Muhammad Azmin \\ Institut Agama Islam Negeri (IAIN) Mataram
}

\begin{abstract}
Abstrak
Ketidaktahuan konsumen terhadap Undang-Undang Nomor 7 Tahun 2014 tentang Perdagangan secara substansinya juga menjadikan produk yang tidak berlabel bahasa Indonesia tetap beredar di Supermarket Niaga Cakara Negara Mataram. Sebagaimana hasil wawancara dengan Muhammad Alfan menyatakan: Saya sering membeli obat pembersih wajah yang pada labelnya tidak menggunakan bahasa Indonesia, karna terbiasa haldemikian tidak membuat saya takut akan dampak negatif dari produk tersebut.Walaupun tanpa bisa menerjemahkan informasi yang tercantum pada produk yang saya gunakan tapi memberikan hasil yang sesuai saya inginkan tanpa adanya rasa dirugikan. Selanjutnya terkait penerapan undang-undang yang mengatur hal yang demikian Mas Muhammad Alfan menyatakan tidak tau sama sekali.
\end{abstract}

Kata Kunci: Produk tidak berlabel, Etika bisnis Islam

\section{A. PENDAHULUAN}

Ada empat sendi utama dalam muamalat Islam, yakni: Ketuhanan, etika, kemanusiaan, dan sikap keterbukaan. Keempat sendi ini member pengaruh bagi aspek kegiatan ekonomomi baik dalam hal produksi, konsumsi, distribusi, masalah ekspor, maupun impor. Produksi adalah kegiatan manusia untuk menghasilkan barang dan jasa yang kemudian dimanfaatkan oleh konsumen. Pada saat kebutuhan manusia masih sedikit dan sederhana, kegiatan produksi dan konsumsi sering kali dilakukan oleh seseorang sendiri. ${ }^{1}$

Terkait dengan itu, produk yang dihasilkan produsen merupakan hal pokok yang harus diperhatikan oleh konsumen agar tidak terjadi hal-hal yang tidak diinginkan dan segala upaya yang menjamin adanya kepastian hokum untuk memberi perlindungan kepada konsumen

${ }^{1}$ Pusat Pengkajian dan Pengembangan Ekonomi Islam (P3EI) Universitas Islam Indonesia Yokyakarta dan Bank Indonesia, Ekonomi Islam(Jakarta: PT Raja Grafindo Persada, 2008), h. 5. 
merupakan perlindungan konsumen. Tetapi, sejauh ini UU Perlindungan Konsumentersebutbelumsepenuhnya ditegakkan. Konsumen sebagai objek UU Perlindungan Konsumen masih saja sering dirugikan oleh para produsen nakal. Oleh karena itu, perlu dilakukan sesuatu agar hal tersebut tidak terjadi, diantaranya penegakan hukum bagi pelaku usaha dalam memproduksi barang sehingga tidak memberikan kerugian kepada konsumendariprodukyangdihasilkan. Dengan ditegakkannya hukum juga dapat membentuk etika dan moral pelaku usaha dalam memproduksi barang.

Pelanggaran yang terjadi dalam bidang muamalah masih sering terjadi dan sering kita lihat, salah satu contohnyaperedaranprodukyangtidak menggunakan label bahasa Indonesia dalam kemasan maupun informasi terkait produk yang dihasilkan pelaku usaha yang diperjualbelikan di wilayah kita. Disamping melanggar ketentuan undang-undang yang merugikan konsumen kesenjangan antara teori dan fakta yang terjadi di kehidupan kita menjadikan hal ini juga sangatlah penting untuk diteliti dikarenakan produk yang diedarkan di wilayah Indonesia yang tidak menggunakan label bahasa Indonesia jelas-jelas sudah melanggar ketentuan Pasal 6 ayat 1 Undang-Undang No 7 Tahun 2014 tentang Perdagangan, yang dimana pasal 6 ini berbunyi: Setiap pelaku usaha wajib menggunakan atau label berbahasa Indonesia pada barang yang diperdagangkan dalam negeri. ${ }^{2}$

Permasalahan ini pula melanggar Peraturan Menteri Perdagangan (Permendag) Nomor 67/M-DAG/ PER/11/2013 tentang Kewajiban Pencantuman Label dalam Bahasa Indonesia pada Barang, terutama untuk produk impor yang masuk ke Indonesia pasal 2 ayat 1 berbunyi: Pelaku usaha yang memproduksi atau mengimpor barang untuk perdagangkan dipasar dalam negeri sebagaimana tercantum dalam lampiran peraturan menteri ini wajib mencantumkan label dalam bahasa Indonesia. $^{3}$

Kesenjangan antara teori dan fakta yang terjadi bisa ditemukan di tempat perbelanjaan pada umumnya khususnya di Supermarket Niaga Cakra Negara Mataram yang penulis langsung temukan produk-produk yang tidak berlabel bahasa Indonesia sebagai data awal penulis. Produk yang penulis temukan tersebut salah satunya adalah produk creem pemutih wajah lakilaki, produk ini beredar dan diperdagangkan di SupermarketNiaga Cakra Negara Mataram dengan label informasinya menggunakan bahasa Inggris seluruhnya tanpa satu katapun menggunakan bahasa Indonesia, hal ini menjadikan bukti nyata kurangnya

\footnotetext{
${ }^{2}$ Undang-Undang Nomor 7 Tahun 2014 te tang Perdagangan (Bandung: Citra Umbara, 2014), h. 9 .

${ }^{3}$ PERMENDAG Nomor 67/M-DAG/ PER/11/2013 tentang Kewajiban Pencantuman Label dalam Bahasa Indonesia pada Barang.
} 
perhatian terhadap penegakan hukum yang ada. ${ }^{4}$

Syariah menaruh keutamaan besar bagi peran informasi dalam pasar, seseorang harus memberikan kesempatan luas kepada klien untuk melihat dan memeriksa komoditas yang akan dibelinya. Informasi yang tidak akurat atau menipu adalah dilarang dan dinilai sebagai dosa. Nabi Muhammad Saw. pernah berkata: "Mendustai seorang Mustarsal (seorang peserta baru/tak dikenal ke dalam pasar) adalah riba".

Umat Islam perlu mengetahui informasi yang jelas tentang halal dan haram pangan dan produk lainnya seperti makanan, minuman, kosmetika, obat, dan barang lain, sesuai firman Allah SWT:

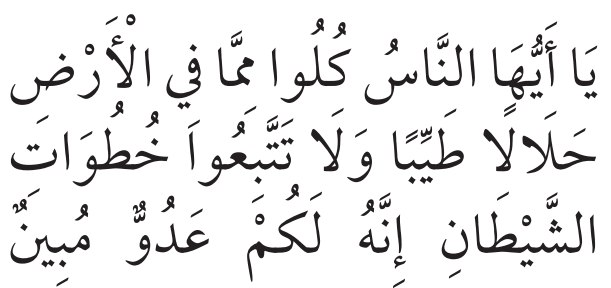

( $\wedge \neg 1)$

Artinya: "Wahai manusia, makanlahapa yang ada di bumi ini secara halal dan baik. Dan janganlah kalian ikuti langkahlangkah setan. Sesungguhnya ia adalah musuh yang nyata bagi kalian"(QS. Al-Baqarah:168). ${ }^{6}$

${ }^{4}$ Observasi, Supermarket Niaga Cakra Neg ra Mataram, 26Februari 2016.

${ }^{5}$ Veithzal Rivai, Amiur Nuruddin, dan Faisar Ananda Arfa, Islamic Business and Economic Ethics Memasyarakatkan Ekonomi Islam, Mengislamkan Ekonomi Masyarakat (Jakarta: Bumi Aksara, 2012), h. 404.

${ }^{6}$ Departemen Agama RI, Al-Quran dan Te jemahnnya (Jakarta: PT.Sinergi Pustaka Indonesia,
Pengaturan barang yang beredar di Indonesia harus mencantumkan informasi dan atau petunjuk penggunaan dalam bahasa Indonesia adalah untuk meyakinkan bahwa sebelum konsumen membeli dan menggunakan produk tersebut, konsumen sudah paham dengan benar tentang produk tersebut, khususnya menyangkut kegunaan/ fungsi dari produk tersebut, spesifikasi produk dan mengerti apa yang boleh dan tidak boleh dilakukan dengan produk tersebut.Produk yang tidak berlabel bahasa Indonesia yang beredar dan diperdagangkan pula dapat dikaitkan dengan pelanggaran etika bisnis Islam yang tidak menegakan keterbukaan, keseimbangan, keadilan dll.

Apalagi Indonesia saat ini menghadapi masyarakat ekonomi Asean, banyak produk luar negeri yang diperdagangkan sehingga tidak menutup kemungkinan produk tanpa menggunakan bahasa Indonesia akan marak beredar diwilayah Indonesia yang belum jelas halal atau haram untukmasyarakatmuslimdalamteknik pemprosesan, penyimpanan, dan penanganan yang sering digunakan bahan pengawet yang membahayakan kesehatan atau bahan tambahan yang mengandung unsur haram yang dilarang dalam agama Islam. ${ }^{7}$

2012), h.32.

${ }^{7}$ Wiku Adisasmito,Analisis Kebijakan N sional MUI dan BPOM dalam Labeling Obat dan Makanan(Depok: Wiku Adisasmito, 2008), h. 12. 
B. ANALAISIS PENERAPAN UNDANG UNDANG NOMOR 7 TAHUN 2014 TENTANG PERDAGANGAN TERHADAP PRODUK YANG TIDAK BERLABEL BAHASA INDONESIA DI SUPERMARKET NIAGA CAKRA NEGARAMATARAM

Dari hasil penelitian yang sudah dilakukan oleh peneliti yang sudah dipaparkan pada bab sebelumnya, maka peneliti dapat menganalisis penerapan Undang-Undang Nomor 7 Tahun 2014 tentang Perdagangan terhadap produk yang tidak berlabel bahasa Indonesia di Supermarket Niaga Cakra Negara Mataram. Undang-undang ini tidak diterapkan sepenuhnya oleh para pelaku ekonomi yang disebabkan oleh kurangnya kesadaran para pelaku ekonomi baik itu dari pelaku usaha, pemerintah maupun masyarakat terhadap penerapan Undang-Undang Nomor 7 Tahun 2014 tentang Perdagangan dalam mengatur produk yang tidak berlabel bahasa Indonesia.

Sebagaimana yang disampaikan oleh Ibu Evi selaku menejer operasional Supermarket Niaga Cakra NegaraMataram menyatakan, walaupun saya tidak mengetahui Undang-Undang Nomor 7 Tahun 2014 tentang Perdagangan, sekiranya ada beberapa penyebab mengapa produk yang tidak berlabel bahasa Indonesia masih beredar diantaranya:

1. Kurangnya kesadaran pelaku usaha dalam memproduksi barang yang didistribusi dan diperdagangkan yang tidak berlabel bahasa Indonesia. atau bisa jadi ketidak tahuan terhadap ketentuan yang mengatur produk yang tidak berlabel bahasa Indonesia yang diatur dalam Undaang-Undang Nomor 7 tahun 2014 tentang Perdagangan.

2. Tidak adanya keberatandari pihak konsumen yang merasa dirugikan sehingga produk yang beredar tidak menjadi suatu masalah yang serius, bahkan produk tersebut terus menerus dikonsumsi karena memberikan keuntungan secara personal oleh konsumen dari produsen. Keuntungan yang terlihat mengalir pada dua arah, baik produser terhadap konsumen lebih-lebih konsumen terhadap produser. Persediaan barang dengan label yang tidak mengguakan bahasa Indonesia dengan mudah dan begitu saja diterima oleh masyarat, bahkan permintaan di pasaran semakin meningkat disebabkan efek yang dirasakan oleh konsumen, sehingga keberatan saja konsumen tidak terlintas dipikirannya.

3. Kurangnya perhatian dari pemerintah dalam mengawasi produk yang beredar dipasaran maupun produk-produk impor yang masuk dari luar negeri yang memberi peluang kontribusi banyak terhadap pelanggaran Undang-Undang No 7 Tahun 
2014 tentang Perdagangan khususnya pada pasal 6 ayat $1 .{ }^{8}$

Ketidaktahuan konsumen terhadap Undang-Undang Nomor 7 Tahun 2014 tentang Perdagangan secara substansinya juga menjadikan produk yang tidak berlabel bahasa Indonesia tetapberedardiSupermarket Niaga Cakara Negara Mataram. Sebagaimana hasil wawancara dengan Muhammad Alfan menyatakan: Saya sering membeli obat pembersih wajah yang pada labelnya tidak menggunakan bahasa Indonesia, karna terbiasa haldemikian tidak membuat saya takut akan dampak negatif dari produk tersebut.Walaupun tanpa bisa menerjemahkan informasi yang tercantum pada produk yang saya gunakan tapi memberikan hasil yang sesuai saya inginkan tanpa adanya rasa dirugikan. Selanjutnya terkait penerapan undang-undang yang mengatur hal yang demikian Mas Muhammad Alfan menyatakan tidak tau sama sekali. ${ }^{9}$

Pada dasarnya UndangUndang Nomor 7 Tahun 2014 tentang Perdagangan dibuat dengan mengedepankan kepentingan nasional dan ditujukan untuk melindungi pasar domestik dalam negeri, membuat regulasi perdagangan dalam negeri dan memberikan perlindungan terhadap konsumen.Undang-undang Perdagangan ini mengamanatkan pedoman teknis yang belum ada turunannya dari peraturan pemerintah

${ }^{8} \mathrm{Ibu}$ Evi, wawancara, Mataram, 19 Mei 2016.

${ }^{9}$ Muhammad Alfan, Wawancara, Mataram, 16 Mei 2016. pusat maupun pemerintah daerah sehingga pada penerapannya di Supermarket Niaga Cakra Negara Mataram menjadi salah satu analisis penulis kenapa Undang-Undang No 7 tahun 2014 tentang Perdagangan ini tidak diterapkan. Secara substansinya UU Nomor 7 Tahun 2014 tentan Perdagangan dalam Pelaksanaan pasal-pasal ke dalam 9 peraturan pemerintah, 14 peraturan presiden, dan 20 peraturan menteri yang diperinci sebagai berikut:

Implementasi Undang-Undang No 7 Tahun 2014 tentang Perdagangan dapat dianalisis dari pelaksanaannya di Supermarket Niaga Cakra Negara Mataram, maka banyak hal yang dapat ditemukan kesenjangannya secara penerapannya.

1. Secara substansi UndangUndang Nomor 7 Tahun 2014 tentang Perdagangan pasal 6 ayat 1 yang berbunyi: Setiap pelaku usaha wajib menggunakan atau melengkapi label berbahasa Indonesia pada barang yang diperdagangkan di dalam negeri, tapi nyatanya produkproduk yang beredar dan diperdagangkan di Supermarket Niaga Cakra Negara Mataram masih saja ditemukan. ndangundang No 7 Tahun 2014 tentang Perdagangan hanya menjadi sebuah aturan yang hanya di tetapkan tapi tidak diterapkan oleh para pelaku ekonomi dalam dunia perdagangan

2. Penegakan hukum yang kurang maksimal oleh badan hukum 
atau pemerintah yang kurang tegas menegakan aturanaturan yang telah dibuat sehingga penyimpangan dalam perdagangan masih saja terjadi.

3. Budaya Hukum konsumen dan pelaku usaha yang kurang taat akan hukum yang berlaku juga menjadikan kegiatan ekonomi sudah keluar dari aturan yang sebagaimana mestinya, seperti halnya peredaran produk yang tidak berlabel bahasa Indonesia di Supermarket Niaga Cakra Negara yang masih saja beredar.

4. Belum adanya Sarana dan Prasarana pemerintah pusat maupun pemerintah daerah dalammendukung UndangUndang No 7 Tahun 2014 tentang Perdagangan ini dalam mengatur peredaran produk yang tidak berlabel bahasa Indonesiaadalah menjadi dasar dari tidak diterapkannya Undang-Undang ini karna bisa dikatakan baru. Oleh karena itu dalam penerapanya pelaku usaha hanya berpedoman pada Undang-Undang yang lama yaitu Undang-Undang Nomor 8 Tahun 1999 tentang Perlindungan Konsumen dengan Peraturan Pemerintah Republik Indonesia Nomor 69 Tahun 1999 tentang Label dan Iklan Pangan.

\section{ANALISIS PERSPEKTIF ETIKA BISNISISLAMTERHADAPPRODUK YANG TIDAK BERLABEL BAHASA INDONESIA DI SUPERMARKET NIAGA CAKRA NEGARA MATARAM}

Secara syariat Islam, Islam turun dengan tujuan menyempurnakan Akhlak manusia dan ahlak tersebut merupakan sesuatu yang harus ditanamkan pada diri setiap orang dalam menjalankan hidup bersosial masyarakat lebih-lebih dalam bermuamalah. Oleh karena itu, secara normative ada beberapa yang harus diperhatikan sebagai pelaku ekonomi khususnya bagi pelaku usaha yang memproduksi barang yang tidak berlabel bahasa Indonesia yang sudah jelas melanggar ketentuan-ketentuan umum dalam etika bisnis Islam.

Sejumlah aksioma dasar (hal yang sudah menjadi umum dan jelas kebenarannya) sudah dirumuskan dan dikembangkan oleh para sarjana muslim. ${ }^{10}$ Aksioma-aksioma tersebut adalah sebagai berikut:

\section{Unity (persatuan)}

Keberdaan produk yang tidak berlabel bahasa Indonesia di wilayah Indonesia khususnya di Supermarket Niaga Cakra Negara Mataram sesuai hasil temuan penulis yang dijelaskan pada bab sebelumnya menjadikan bukti tidak ditegakannya ketentuan umum oleh pelaku usaha dalam memberikan kemudahan informasi dari produk yang dikonsumsi sehingga nilai kesatuan dan persatuan tidak

${ }^{10}$ Faisal Badroen,dkk, Etika Bisnis...h. 88. 
diterapkan dalam dunia usaha. Dalam kegiatan ekonominya Supermarket Niaga Cakra Negara Mataram membeli barang dari luar kota melalui Supplier/distributor tanpa catatan khusus produk tersebut menggunakan label berbahasa Indonesia atau tidak, sehingga jumlah produk yang peredarpun tidak dapat diketahui secara pasti.Produk-produk tersebut kebanyakan menggunakan bahasa Inggris secara bahasa inggris sebagai bahasa dunia.

Di Supermarket Niaga Pula diperdagangkan berbagai macam jenis produk yang bisa dikonsumsi secara langsung. Setiap individuindividu memiliki kesamaan dalam harga dirinya sebagai manusia. Diskriminasi tidak bisa diterapkan atau dituntut hanya berdasarkan warna kulit, ras, kebangsaan, agama jenis kelamin, atau umur. Hak-hak dan kewajiban-kewajiban ekonomik setiap individu disesuaikan dengan kapabilitas dan kapasitas yang dimiliki dan singkronisasi pada setiap peranan normatif masing-masing dalam struktur sosial. Berdasarkan hal inilah, beberapa perbedaan peranan muncul antara orang-orang dewasa, di satu pihak, dan orang jonpo atau remaja, di satu pihak, dan orang jonpo atau remaja, dipihak lain, atau antara lakilaki dan perempuan.

Dalam persatuan, solidaritas sosial dapat diwujudkan dari suatu persaudaraan antara sesama manusia lebih-lebih persaudaraan muslim bersama muslim lainya. Sesuai Firman
Allah SWT di dalam Qur'an surat AlHujurat ayat 10 yang berbunyi:

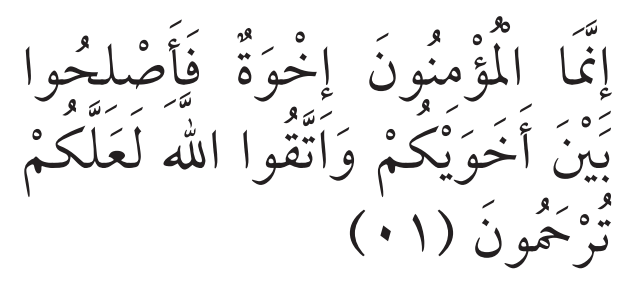

Artinya: Orang-orang beriman itu Sesungguhnya bersaudara.sebab itu damaikanlah (perbaikilah hubungan) antara kedua saudaramu itudan takutlah terhadap Allah, supaya kamu mendapat rahmat (Qs.Al-Hujurat : 10). ${ }^{11}$

Sehingga analisis penulis bagi pelaku ekonomi khususnya produsen yang memproduksi dan memperdagangkan produk yang tidak berlabel bahasa Indonesia seperti di Supermarket Niaga Cakra Negara Mataram tidak harus dilakukan di wilayah Republik Indonesia yang mayoritas orang muslim dan demikian pula merupakan hal yang sudah tidak relevan dengan kapabilitas dan kapasitas masyarakat dalam stratifikasi sosial.

\section{Equilibrium (keseimbangan)}

Peredaran produk yang tidak berlabel bahasa Indonesia di Supermarket Niaga Cakra Negara Mataram merupakan sesuatu yang dipandang melanggar keadilan bagi konsumen yang tidak mengetahui secara pasti penggunaan produk yang dikonsumsi sebagaimana hasil wawancara dengan Ibu Wahyuniarti, mengatakan bahwa walaupun persaingan di era globalisasi seperti ini, tidak boleh memperjualbelikan

${ }^{11}$ Departemen Agama RI, Al-Quran..., h. 744. 
barang yang tidak menggunakan label bahasa Indonesia sebab hal ini merupakan sesuatu yang tidak adil karena banyak pihak yang dirugikan, banyak masyarakat yang tidak bisa mengerti bahasa asing. Sehingga boleh saja akan memberikan dampak yang berakibat fatal bagi yang mengkonsumsinya atau bisa saja produk tersebut sudah kadaluwarsa tetapi masih diperjualbelikan sehingga dapat beresiko fatal bagi yang mengkonsmsinya. ${ }^{12}$

Dalam beraktivitas di dunia kerja dan bisnis, Islam mengharuskan untuk berbuat adil, tak terkecuali kepada pihak yang tidak disukai. Pengertian adil dalam Islam diarahkan agar hak orang lain, hak lingkungan sosial, hak alam semesta dan hak Allah dan rasulnya berlaku sebagai stakeholder dari perilaku adil seseorang. Semua hak-hak tersebut harus ditempatkan sebagaimana mestinya (sesuai aturan syariah), Tidak mengakomodir salah satu hak diatasdapat menempatkan seseorang tersebut pada kezaliman. Karenanya orang yang adil akan lebih dekat kepada ketakwaan, Allah berfirman:

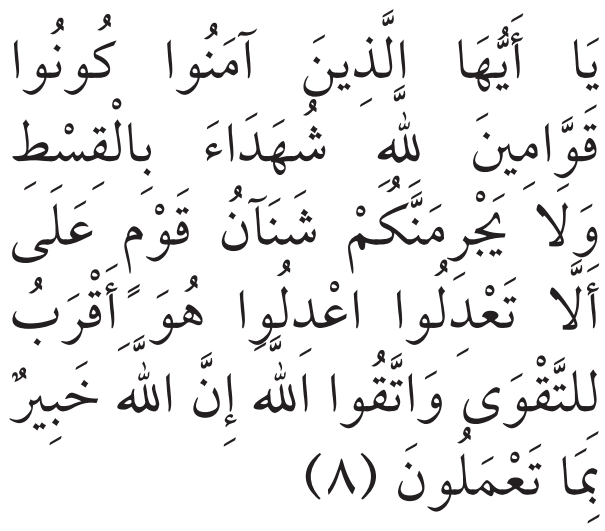

${ }^{12} \mathrm{Ibu}$ Wahyuniarti, Wawancara, Mataram, 20 Mei 2016.
Artinya : Hai orang-orang beriman, hendaklah kamu jadi orangorang yang selalu menegakkan (kebenaran) karenaAllah, saksi dengan adil. Dan janganlah sekalikali kebencianmu terhadap suatu kaum, mendorong kamu untuk berlaku tidak adil. Berlaku adillah karena adil itu lebih dekat dengan takwa dan bertakwalah kepada Allah, 71 sesungguhnya Allah mengatahuai apa yang kamu kerjakan (QS. Al-Maidah:8)56

Berlaku adil akan dekat dengan takwa, karena itu dalam perniagaan (tijarah), Islam melarang untuk menipu walaupun hanya sekedar membawa sesuatu pada kondisi yang menimbulkan keraguan sekalipun. atau karena adanya informasi penting mengenai transaksi yang tidak diketahui oleh salah satu pihak (asymetric information).Moral hazard (perilaku menzolimi) adalah hal yang sangat penting, oleh sebab itu, keseimbangan moral muslim mengarahkan untuk tidak membikin mudharãt (kesulitan) dan mafsadãt (kerusakan).

Sehingga analisis peneliti terhadap produk yang dihasilkan oleh pelaku usaha dengan tidak menggunakan label berbahasa Indonesia adalah suatu yang memberikan mudharãt(kesulitan) bagi konsumen dalam memperoleh informasi produk yang telah dihasilkan. Sehingga hal yang sifatnya mudharãtdalam bidang muamalah harus dilenyapkan tanpa 
mempertimbangkan niat yang melatarbelakanginya.

Anjuran untuk berlaku adil juga telah Allah SWT berfirman juga pada surat surat An-nahl ayat 90 yang berbunyi:

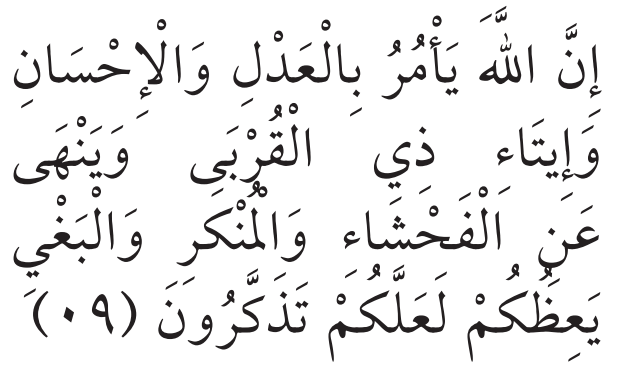

Artinya: Sesungguhnya Allah menyuruh (kamu) berlaku adil dan berbuat kebajikan, memberi kepada kaum kerabat, dan Allah melarang dari perbuatan keji, kemungkaran dan permusuhan.dia memberi pengajaran kepadamuagarkamudapatmengambil pelajaran(Qs.An-Nahl: 90). ${ }^{13}$

3. Free Will (kehendak bebas).

Menurut Rian Fiqih Mahasiswa Universitas Mataram Fakultas Hukum, produk dengan label yang tidak menggunkan bahasa Indonesia tidak boleh diedarkan, karena kita hidup di negara hukum, berarti kita harus tunduk pada segala hukum yang mengatur. Kemerdekaan Indonesia diartikan sebagai kebebasan dan kebebasan itu bukan berarti tutup mata terhadap aturan yang berlaku di Indonesia. ${ }^{14}$

Manusia adalah maujud merdeka yang melaksanakan aksinya atas dasar ilmu, kehendak dan kebebasannya.

\footnotetext{
${ }^{13}$ ibid., h. 377.

${ }^{14}$ Rian Fiqih,Wawancara, Mataram, $20 \mathrm{Mei}$ 2016.
}

Pelaku usaha bebas memproduksi dan memperdagangkan produk yang tidak berlabelbahasaIndonesia sebagaimana yang dapat dilihat Supermarket Niaga Cakra Negara Mataram yang sangat marak peredaranya baik dapat dilihat dari berbagai jenis produk, seperti bahan pangan, kosmetik, pakaian, dan barangelektronikyangdapat dinikmati oleh para pengunjung Supermarket Niaga Cakra Negara Mataram.

Firman Allah di dalam Al-Quran yang memberbicarakan tentang kebebasan salah satunya adalah Surat Al-Imran ayat 145 yang berbunyi :

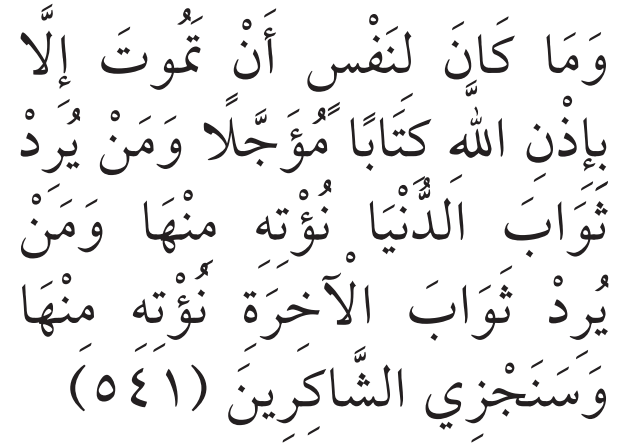

Artinya : Sesuatu yang bernyawa tidak akan mati melainkan dengan izin Allah, sebagai ketetapan yang Telah ditentukan waktunya. barang siapa menghendaki pahala dunia, niscaya kami berikan kepadanya pahala dunia itu, dan barang siapa menghendaki pahala akhirat, kami berikan (pula) kepadanya pahala akhirat itu. dan kami akan memberi balasan kepada orang-orang yang bersyukur. (Qs. Al-Imran:145). ${ }^{15}$

Sehingga analisis penulis setiap manusia bebas melakukan bentuk usaha apapun dalam memperoleh keuntungan sesuai yang dihendaki

${ }^{15}$ Departemen Agama RI, Al-Quran..., h. 86. 
masing-masing individu, akan tetapi kebebasan tersebut harus merujuk padaketentuan peraturanyangberlaku baik dalam hukum positif maupun hukum Islam yang menegakan hak-hak orang lain. Menghasilkan produk yang tidak berlabel bahasa Indonesia dengan mengedarkan dan memperdagangkannya merupakan kebebasan setiap pelaku usaha, dan kebebasan tersebut sudah menyalahi ketentuan-ketentuan yang berlaku dalam bisnis Islam dikarenakan sudah menyalahi arti dari kebebasan yang sebenarnya.

\section{Responsibility(tanggung jawab).}

Peredaran produk yang tidak berlabelbahasa Indonesia sebagaimana dapat dilihat di Supermarket Niaga Cakra Negara Mataram merupakantidak adanya tanggung jawabpelakuusahadalammenjalankan usahanya sesuai peraturan yang berlaku.Konsumen pula banyak yang tidak menyadari tanggung jawabnya terhadap dampak yang akan teradi jika mengonsumsi produk yang sudah jelas melanggar aturan-aturan yang berlaku. Selain itu tidak adanya tanggung jawab pemerintah dalam penegakan hukum terhadap produk yang beredar di Supermarket Niaga Cakra Negara Mataram adalah faktor penyebab beredarnya produk yang tidak berlabel bahasa Indonesia dari berbagai pendapat informen yang dijelaskan pada bab sebelumnya.

Syariah menaruh keutamaan besar bagi peran informasi dalam pasar, seseorang harus memberikan kesempatan luas kepada klien untuk melihat dan memeriksa komoditas yang akan dibelinya. Informasi yang tidak akurat atau menipu adalah dilarang dan dinilai sebagai dosa. Nabi Muhammad Saw pernah berkata: "Mendustai seorang Mustarsal (seorang peserta baru/tak dikenal ke dalam pasar) adalah riba” ${ }^{16}$

Aksioma tanggung jawab individu begitu mendasar dalam ajaranajaran Islam, terutama jika dikaitkan dengan kebebasan ekonomi. Penerimaan pada prinsip tanggung jawab individu ini berarti setiap orang akan diadili secara personal dari hari kiamat kelak. Tidak ada satu carapun bagi seorang untuk melenyapkan perbuatan-perbuatan jahatnya kecuali dengan memohon ampunan Allah dan melakukan perbuatan-perbuatan yang baik (amal saleh). Islam sama sekali tidak mengenal konsep dosa warisan, (dan karena itu) tidak ada seorang bertanggung jawab atas kesalahan orang lain. ${ }^{17}$ Tanggung jawab tersebut dapat ditanggung masingmasing, berdasarkan ayat Qur'an suratAl-An'am ayat 164 yang berbunyi:

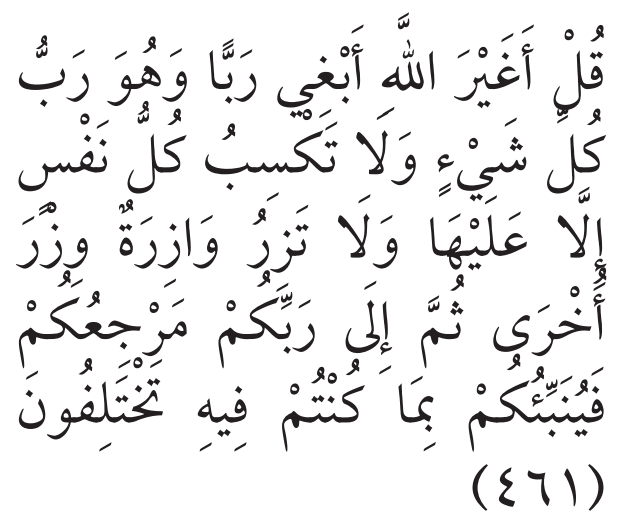

${ }^{16}$ Veithzal Rivai, Amiur Nuruddin,dan Faisar Ananda Arfa, Islamic Business and Economic Ethics Memasyarakatkan Ekonomi Islam, Mengislamkan Ekonomi Masyarakat (Jakarta: Bumi Aksara, 2012), h. 404 .

${ }^{17}$ Faisal Badroen,dkk, Etika Bisnis...h. 100. 
Artinya: Dan tidaklah seorang membuat dosa melainkan kemudharatannya kembali kepada dirinya sendiri, dan seorang yang berdosa tidak akan memikul dosa orang lain. Kemudian kepada tuhanmulah kamu kembali, dan akan diberitakan-Nya kepadamu apa yang kamu perselisihkan (Qs. Al-An'am ayat 164). ${ }^{18}$

Sehingga analisis peneliti terhadap pelaku usaha yang memproduksi barang yang tidak berlabel bahasa Indonesia harus bertanggung jawab atas produk yang dihasilkan dengan siap menerima konsekuensi di akhirat kelak apabila terdapat hal-hal tercela dalam menjalankan usaha sebagaimana menghasilkan produk yang tidak berlabel bahasa Indonesia, dan tanggung jawab pemerintah dalam menegakan ketentuan-ketentuan yang berlaku serta tanggung jawabnya dalam mengawasi peredaran produk yang tidak berlabel bahasa Indonesia yang merupakan aturan yang telah dibuatnya sendiri. Begitu pula tanggung jawab konsumen dalam mengonsumi barang yang haram maupun halal sebagaimana yang telah dijelaskan dalam agama Islam.

\section{Benevolence(ihsan)}

Peredaran produk yang tidak berlabel bahasa Indonesia di Supermarket Niaga Cakra Negara Mataram merupakan suatu yang jauh dari kata ihsan karena tidak mengandung unsur kebaikan bagi

\footnotetext{
${ }^{18}$ Departemen Agama RI, Al-Quran..., h. 202.
}

konsumen dalam memperoleh informasi produk, serta dinilai sebagai pelanggaran aturan yang berlaku. Sebagaimana wawancara denganNur Arafah yang menyatakan: Jikaproduk yang tidak berlabel bahasa Indonesia sudah jelas melanggar Undang-Undang Nomor 7 Tahun 2014 tentang Perdagangan dalam pasal 6 berarti setiap kegiatan dalam memproduksi,mendistribusi maupun mengonsumsinya adalah suatu yang sudah tidak baik dilakukan bagi para pelaku ekonomi. ${ }^{19}$

Ihsan artinya melaksanakan perbuatanbaikyangdapatmemberikan kemanfaatan kepada orang lain, tanpa adanya kewajiban tertentu untuk mengharuskan perbuatan tersebut atau dengan kata lain beribadah dan berbuat baik seakan-akan melihat Allah, jika tidak mampu, maka yakinlah Allah melihat. ${ }^{20}$

Aspek ihsan dalam muamalah ini dijelaskan Allah SWT pada surah An-Nisa' ayat 36 yang berbunyi:

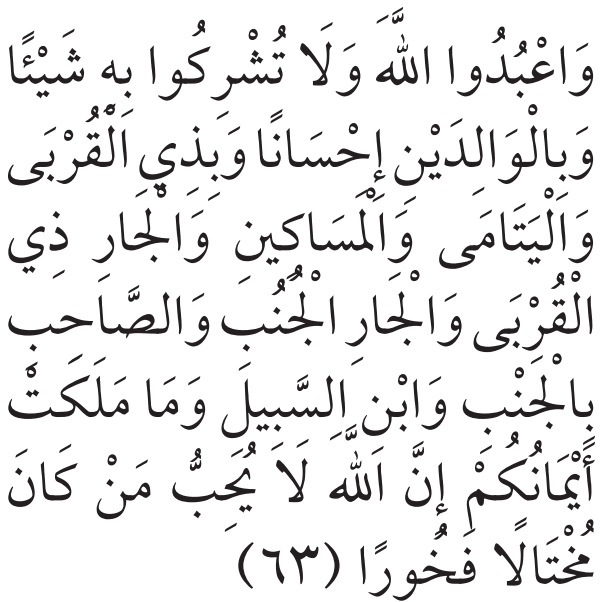

\footnotetext{
${ }^{19}$ Nur Arafah, Wawancara, Mataram, 12 Juni 2016.

${ }^{20}$ Faisal Badroen,dkk, Etika Bisnis...h. 103.
} 
Artinya: Sembahlah Allah dan janganlah kamu mempersekutukanNya dengan sesuatupun. Dan berbuat baiklah kepada dua orang ibu bapak, karib-kerabat, anakanak yatim, orang-orang miskin, tetangga yang dekat dan tetangga yang jauh, dan teman sejawat, ibnu sabil dan hamba sahayamu. Sesungguhnya Allahtidakmenyukai orang-orang yang sombong dan membangga-banggakan diri.(Qs. An-Nisa:36). ${ }^{21}$

Dari ayat diatas dapat dianalisis dalam memproduksi produk yang tidak berlabel bahasa Indonesia merupakan perilaku pelaku usahayang tidak mempunyai dasar ihsan karena sudah menyalahi ketentuan Allah serta kurangnya unsur kebaikan untuk orang lain pada bidang muamalah khususnya terkait informasi yang kurang dipaham serta suatu yang sudah melanggar hukum positif khususnya Undang-Undang Nomor 7 Tahun 2014 tentang Perdagangan sebagaimana yang dijelaskan pada pasal 6 ayat 1 .

\section{KESIMPULAN}

1. Implementasi Undang-Undang No 7 Tahun 2014 tentang Perdagangan penerapanya di Supermarket Niaga Cakra Negara Mataram hanya ditetapkan tapi tidak diterapkan dikarenakan: a) Secara substansi Undang-Undang Nomor 7 Tahun

\footnotetext{
${ }^{21}$ Departemen Agama RI, Al-Quran..., h.
} 109.
2014 tentang Perdagangan pasal 6 ayat 1 yang berbunyi: Setiap pelaku usaha wajib menggunakan atau melengkapi label berbahasa Indonesia pada barang yang diperdagangkan di dalam negeri, tapi nyatanya produk-produk yang beredar dan diperdagangkan di Supermarket Niaga Cakra Negara Mataram masih saja ditemukan. b) Penegakan hokum yang kurang maksimal oleh badan hukum atau pemerintah yang kurang tegas menegakan aturan-aturan yang telah dibuat sehingga penyimpangan UU No 7 Tahun 2014 tentang Perdagangan masih saja terjadi. c) Budaya Hukum konsumen dan pelaku usaha yang kurang taat akan hukum yang berlaku juga menjadikan kegiatan ekonomi sudah keluar dari aturan yang sebagaimana mestinya.d)BelumadanyaSarana dan Prasarana pemerintah pusat maupun pemerintah daerah dalam mendukung UndangUndang No 7 Tahun 2014 tentang Perdagangan ini dalam mengatur peredaran produk yang tidak berlabel bahasa Indonesia.

2. Peredaran produk yang tidak berlabel bahasa Indonesia di Supermarket Niaga Cakra Negara Mataram merupakan suatu yang melanggar ketentuan umum dalam etika bisnis Islam dianataranya: (a)Unity (persatuan), yakni hak-hak dan kewajiban-kewajiban ekonomi 
setiap individu disesuaikan dengan kapabilitas dan kapasitas yang dimiliki dan singkronisasi pada masing-masing dalam struktur sosial. (b)Equilibrium (keseimbangan), berlaku adil akan dekat dengan takwa, karena itu dalam perniagaan Islam melarang untuk menipu walaupun hanya sekedar membawa sesuatu pada kondisi yang menimbulkan keraguan sekalipun atau karena adanya informasi penting mengenai transaksi yang tidak diketahui oleh salah satu pihak. (c) Free Will(kehendak bebas), setiap pelaku ekonomi bebas melakukan ekonomi dengan memperhatikan hukum yang berlaku, baik hukum positif maupun hukum Islam. (d) Responsibility(tanggung jawab), pada prinsip tanggung jawab individu berarti setiap orang akan diadili secara personal dari hari kiamat kelak. Tidak ada satu carapun bagi seorang untuk melenyapkan perbuatanperbuatan jahatnya kecuali memohon ampun kepada Allah SWT. (e)Benevolence(ihsan), artinya melaksanakan perbuatan baik yang dapat memberikan kemanfaatan kepada orang lain, dengan kata lain beribadah dan berbuatbaikseakan-akan melihat Allah, jika tidak mampu, maka yakinlah Allah melihat kita.

\section{DAFTAR PUSTAKA}

Al-Fatih, The Holy Qur'an, Jakarta Timur: PT Insan Media Pustaka, 2013.

Burhan Ashshofa, Metodelogi Penelitian Hukum ,Jakarta: PT.Rineka Cipta, 1996.

C.S.T. Kansil, dan Christine, Kansil, Pokok-pokok Pengetahuan Hukum Dagang Indonesia, Jakarta: Alfabeta, 2002.

Departemen Agama RI, Al-Quran dan Terjemahan, Jakarat: PT Sinargi

Pustaka Indonesia, 2012.

Faisal Badroen,dkk, Etika Bisnis dalam Islam,Cet. II. Jakarta: Kencana, 2007.

Hazrul Sani, "Etika Produksi Perspektif Islam Studi Kasus tentang Penembangan Emas, Skripsi IAIN Mataram, Mataram: 2013.

Ilfi Nur Diana, Hadsit-Hadist Ekonomi. cet. I Malang: Sukses Offset, 2008.

Iting Partadireja, Pengetahuan dan Hukum Dagang Jakarta: Erlangga, 1978.

Lexy J. Moleong, Metode Penelitian Kualitatif, Bandung: PT. Remaja Rosdakarya, 2008.

Matthew B Miles dan A. Michael Huberman, Analisis Data Kualitatif BukuBSumber Tentang Metode-Metode Baru, Jakarta: UI-Press, 1992.

M. Burhan Bungin, Penelitian Kualitatif Komunikasi,Ekonomi, 
Kebijakan Publik, dan Ilmu Sosial Lainnya, Jakarta: Kencana, 2007.

Moh. Pabundu Tika, Metodologi Riset BisniS. Cet. I.Bandung: PT Bumi Aksara, 1992.

Muhammad Djakfar, Etika Bisnis Islami Tataran Teoritis dan Praksis, Cet. I Malang:UIN Malang Press, 2008.

Permendag Nomor 67/M-DAG/ PER/11/2013 tentangKewajiban Pencantuman Label dalam Bahasa Indonesia pada Barang.

Puji Astuti, "Pengaruh Penggunaan BahasaArabTerhadapPemasaran Produk Bank Syariah” Skripsi, IAIN Mataram, Mataram: 2007.
Pusat Pengkajian dan Pengembangan ekonomi Islam(P3EI) Universitas IslamIndonesia Yokyakarta dan Bank Indonesia, Ekonomi Islam, Jakarta: PTRaja Grafindo Persada, 2008.

Sugiono.Metode Penelitian Manajemen Pendekatan Kuantitatif, Kualitatif, Kombinasi, Penelitian Tindakan, Penelitian Evaluasi, Bandung: Alfabeta, 2013.

Undang-Undang Republik Indonesia No 7 Tahun 2014 tentang Perdagangan, Bandung: Citra Umbara 2014.

Wiku Adisasmito, Analisis Kebijakan Nasional MUI dan BPOM dalam Labeling Obat dan Makanan, Depok: ,Wiku Adisasmito, 2008. 